\title{
Pre-harvest desiccation with glyphosate and quality of stored soybean seeds
}

\section{Dessecação em pré-colheita com glifosato e qualidade de sementes armazenadas de soja}

\author{
Mariana Zampar Toledo ${ }^{1 *}$; Mariane Sayuri Ishizuka²; Cláudio Cavariani³; \\ José de Barros França-Neto ; Laís Bilia Picoli ${ }^{2}$
}

\begin{abstract}
Seeds from non-genetically modified soybean cultivars harvested after chemical desiccation of plants with glyphosate may produce abnormal seedlings; these may show phytotoxicity symptoms that could persist even after some time of storage due to accumulation of toxic residues. This study aimed to evaluate the quality of stored soybean seeds harvested after chemical desiccation of plants with glyphosate at R7 stage. Seeds from soybean cultivar 'Conquista' were produced with and without desiccation with glyphosate, at the dose $2.0 \mathrm{~L} \mathrm{ha}^{-1}$, applied at physiological maturity stage. Seed quality was evaluated right after harvest and after eight months of storage by tests of moisture content, mass, germination and vigor. The experimental design was the completely randomized block with four replications. Data was submitted to variance analysis and means were compared by the Tukey test $(\mathrm{p} \leq 0.05)$ as a $2 \times 2$ factorial. The results show deleterious effects of glyphosate used as desiccant for early harvest of soybean seeds from conventional cultivars. Accelerating plant senescence leads to production of seeds with lower germination and decreased seedling development, although the percentage of abnormal seedlings is reduced after 8 months of storage possibly due to degradation of toxic residues of glyphosate and/or derivates.
\end{abstract}

Key words: Glycine max, phytotoxicity, physiological maturity, germination, seedling development

\section{Resumo}

Sementes de cultivares convencionais de soja colhidas após dessecação química das plantas com glifosato podem produzir plântulas anormais, com sintomas de fitotoxicidade que podem persistir mesmo após o armazenamento devido ao acúmulo de resíduos tóxicos. Este trabalho objetivou avaliar a qualidade de sementes armazenadas de soja colhidas após dessecação química das plantas com glifosato no estádio R7. Sementes de soja da cultivar Conquista foram produzidas com e sem dessecação das plantas com glifosato, na dose de $2,0 \mathrm{~L} \mathrm{ha}^{-1}$, no estádio de maturidade fisiológica. A qualidade das sementes foi avaliada logo após a colheita e aos oito meses de armazenamento quanto ao teor de água, massa, germinação e vigor. O delineamento experimental foi o inteiramente casualizado, com quatro repetições. Os dados foram submetidos à análise de variância e as médias comparadas pelo teste de Tukey $(p \leq 0,05)$, em esquema fatorial $2 \times 2$. Os resultados mostram efeitos deletérios da aplicação de glifosato utilizado como dessecante para antecipação da colheita de sementes de soja de cultivares

\footnotetext{
${ }^{1}$ Prof $^{a}$ Dr $^{\mathrm{a}}$ da Faculdade de Ciências Exatas e da Terra, Centro Universitário da Grande Dourados, UNIGRAN, Dourados, MS, Brasil. E-mail: mariana.toledo@unigran.br

2 Discentes do Curso de Graduação em Agronomia, Faculdade de Ciências Agronômicas, FCA/UNESP, Botucatu, SP, Brasil. E-mail:msishizuka@fca.unesp.br; lbpicoli@fca.unesp.br

3 Prof. Dr. da FCA/UNESP, Botucatu, SP, Brasil. E-mail: ccavariani@fca.unesp.br

${ }^{4}$ Dr. e Pesquisador, Embrapa Soja, Londrina, PR, Brasil. E-mail: jose.franca@embrapa.br

* Author for correspondence
} 
convencionais. A aceleração da senescência das plantas resulta na produção de sementes com menor germinação e reduzido desenvolvimento de plântulas, apesar de a porcentagem de plântulas anormais ser reduzida após 8 meses de armazenamento, possivelmente devido à degradação dos resíduos tóxicos de glifosate e/ou seus derivados.

Palavras-chave: Glycine max, fitotoxicidade, maturidade fisiológica, germinação, desenvolvimento de plântulas

Seeds play an important role in the evolution of Brazilian agriculture, which justifies all efforts from seed producers to ensure high quality and solidify the basis to successful yields, which means supplying viable and vigorous seeds so that plants can express their highest genetic potential. In this context, physiological maturity or R7 is defined as a development stage when seeds show maximum dry matter accumulation, germination and vigor (CARVALHO; NAKAGAWA, 2012). Therefore, harvesting seeds at or close to this stage would ensure better quality at minimum deterioration levels.

Soybean (Glycine $\max$ (L) Merrill) seed producers have attempted to anticipate harvest through chemical desiccation of plants, especially with paraquat and diquat (LACERDA et al., 2003). Nevertheless, glyphosate has also been applied as desiccant to accelerate and homogenize water loss by plants and seeds. Glyphosate is a non-selective and efficient herbicide widely applied in many Brazilian regions (VARGAS; MORAES; BERTO, 2007), although inappropriate use may cause phytotoxicity in plants, as well as grain yield and seed quality loss.

Although transgenics are widely cultivated in Brazil, there apparently is a possibility of genetically and non-genetically modified soybean to coexist; nevertheless, some difficulties are still faced by importer and exporter countries, mainly related to keeping lots of conventional soybean free from contamination with genetically modified cultivars (MENDEZ DEL VILLAR et al., 2007).

Pre-harvest desiccation of soybean plants from non-genetically modified cultivars for seed production is not recommended, once physiological quality and development of primary roots in seedlings may be harmed (TECNOLOGIAS, 2011). Gazziero and França Neto (2008) reported negative effects of pre-harvest desiccation with glyphosate on seedling development of two soybean cultivars. Similarly, Penckowski, Podolan and López-Ovejero (2005) evaluated quality of soybean and bean (Phaseolus vulgaris L.) seeds, respectively, and found glyphosate application to be detrimental to germination.

Many studies have brought out relevant effects of chemical desiccation such as accumulation of toxic residues in seeds and influence on germination and vigor; however, results are yet inconclusive. Nevertheless, Dick and Quinn (1995) observed that modifications in plant physiology and, consequently, seed quality are mainly due to compounds originated from glyphosate degradation, such as the aminomethylphosphonic acid (AMPA), rather than glyphosate itself. This substance is accumulated in seeds (DUKE et al., 2003) and may cause abnormalities to seedlings. Considering that glyphosate metabolites are formed gradually, it is possible that negative effects of pre-harvest desiccation in soybean seed quality vary during storage. Additionally, the response of orthodox seeds to drying initially depends on desiccation conditions.

In this context, this study aimed to evaluate quality of stored soybean seeds harvested after chemical desiccation of plants with glyphosate at R7 stage.

This study was conducted in Botucatu-SP, Brazil. Geographical coordinates are $48^{\circ} 23^{\prime} \mathrm{W}$, $22^{\circ} 51^{\prime} \mathrm{S}$ and $765 \mathrm{~m}$ asl. Soil in the area is a Typic Hapludox (FAO, 2006). According to Köeppen's 
classification, climate is Cwa, which corresponds to tropical altitude with dry winter and hot wet summer.

Figure 1 shows climate data recorded in the area during the experiment.
The experimental design was the completely randomized block with four replications. Treatments consisted of pre-harvest desiccation of soybean plants with glyphosate at physiological maturity stage and a control.

Figure 1. Mean rainfall (ש巛Z) and temperature (-) during the experiment in Botucatu-SP, Brazil. S: sowing; PM: physiological maturity.

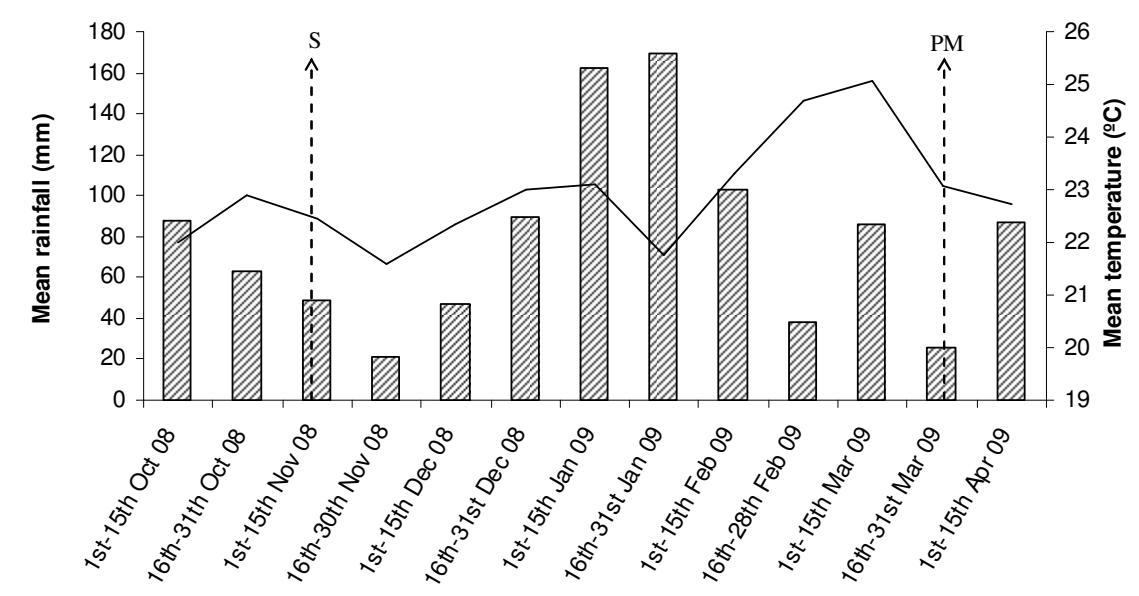

Source: Elaboration of the authors.

Soybean was cropped in four 12-m long x 5-m wide blocks. A 4-m long corridor was established among blocks for traffic.

Non-genetically modified soybean cultivar 'Conquista' was sown mechanically over millet residues on 04 Nov. 2008. Seeds were previously treated with carboxim+thiram fungicide (Vitavax Thiram $\mathrm{SC}^{\circledR}-300 \mathrm{~mL}$ per $100 \mathrm{~kg}$ of seeds) and inoculant (Biomax Premium Turfa ${ }^{\circledR}-60 \mathrm{~g}$ per 50 $\mathrm{kg}$ of seeds) and sown at $0.45-\mathrm{m}$ row spacing to obtain a population of 400,000 plants $\mathrm{ha}^{-1}$. Base fertilization consisted of $300 \mathrm{~kg} \mathrm{ha}^{-1}$ of the $04-20-20$ NPK formula.

Glyphosate was applied at a dose of $2.0 \mathrm{~L} \mathrm{ha}^{-1}$ (Roundup $\mathrm{WG}^{\circledR}-720 \mathrm{~g}$ a.i. $\mathrm{kg}^{-1}$ ) at physiological maturity stage, or R7, that occurred on 24 March 2009. This growth stage was identified through pod staining, i.e. most of them yellowish and one completely mature in the main stem (FEHR; CAVINESS, 1977). The application was carried out with spraying bar with flat fan TJ110.04 nozzles spaced $0.50-\mathrm{m}$ apart from each other. Water volume and application pressure were $200 \mathrm{~L} \mathrm{ha}^{-1}$ and $50 \mathrm{lbf}$ $\mathrm{cm}^{-2}$, respectively.

Seeds were harvested mechanically in 6 lines of 6-m length, totaling $16.2 \mathrm{~m}^{2}$. Afterwards, they were dried and stored in paper bags in dry chamber (30-40\% relative humidity and no temperature monitoring) during the evaluations.

Physiological quality was assessed right after harvest and 8 months after storage, by the following tests:

Water content: two subsamples of 20 seeds per replication were evaluated using an oven at $105 \pm$ $3^{\circ} \mathrm{C}$ for $24 \mathrm{~h}$ (wet basis); results were expressed as a percentage (BRASIL, 2009).

Germination: four subsamples of 50 seeds per replication were distributed on paper towels moistened with water equivalent to 2.5 the weight 
of the dry paper. Rolls were made and placed into plastic bags and left for germination at $25^{\circ} \mathrm{C}$. Evaluation took place eight days after sowing (BRASIL, 2009) and results were expressed as the mean percentage of normal and abnormal seedlings.

First count of germination: it was performed along with the germination test; the percentage of normal seedlings was recorded on the fifth day after sowing (BRASIL, 2009).

Seed mass: eight replications of 100 seeds were counted and weighed according to adaptations of Brasil (2009).

Electrical conductivity: four subsamples of 50 seeds per replication were weighed and soaked into 200-mL plastic cups containing $100 \mathrm{~mL}$ of distilled water, for $24 \mathrm{~h}$ at $25^{\circ} \mathrm{C}$ (VIEIRA; KRZYZANOWSKI, 1999); afterwards, the electrical conductivity ( $\mu \mathrm{S}$ $\mathrm{cm}^{-1} \mathrm{~g}^{-1}$ ) of the solution was determined through reading in a conductivimeter.

Accelerated aging: as described by Marcos Filho (1999), 200 seeds per replication were arranged on accelerated aging trays and placed in plastic boxes $(11.0 \times 11.0 \times 3.5 \mathrm{~cm})$ containing $40 \mathrm{~mL}$ of water at the bottom. The boxes were closed and placed inside plastic bags to minimize water loss. Afterwards, samples were kept inside specific equipment (Hitachi MT10) for accelerated aging at $42^{\circ} \mathrm{C}$ for 24 hours. Right after this period, four subsamples of 50 seeds per replication were evaluated by the germination test as described previously. Evaluation took place five days after sowing (BRASIL, 2009) and results were expressed as the mean percentage of normal seedlings. Moisture content was monitored after the aging period.

Seedling length: four replications of ten seeds per treatment were sown on a line drawn on paper towels moistened with water equivalent to 2.5 times the weight of the dry paper. Rolls were made and placed into plastic bags and left for germination in upright position at $25^{\circ} \mathrm{C}$ for 5 days (NAKAGAWA, 1999). Hypocotyl, primary root and total length of seedlings were measured in $\mathrm{cm}$.
Seedling dry matter: normal seedlings of the seedling length test were placed into paper bags and dried using an oven at $80^{\circ} \mathrm{C}$ for $24 \mathrm{~h}$. Results were obtained dividing each weight by the number of normal seedlings (NAKAGAWA, 1999). Then, the means were obtained for each treatment, in $\mathrm{mg}$.

The experimental design was the completely randomized with four replications. Data was submitted to variance analysis. Means were compared by the Tukey test $(p \leq 0.05)$ and analyzed as a $2 \times 2$ factorial (with/without desiccation $\mathrm{x}$ storage period). Data was also submitted to Pearson's linear correlation test $(\mathrm{p} \leq 0.05)$.

Soybean seeds produced with and without desiccation with glyphosate showed $13.5 \%$ and $14.8 \%$ moisture content, respectively, right after harvest. Those results did not influence subsequent evaluations, as well as moisture means obtained after 8 months of storage, of $6.0 \%$ and $5.9 \%$ for those same treatments.

Seed germination was decreased by the application of glyphosate in R7 stage in any storage periods both in the first and second counts compared to means from conventional production, without pre-harvest desiccation (Table 1). Additionally, whenever glyphosate was applied, it was found that germination was increased as time went by, implying that toxic residues may be degraded after somestorage time. Apparently, according to Hoagland and Duke (1983) and Holliday and Keen (1982), glyphosate reduces isoflavone levels whenever applied in non-genetically modified soybean cultivars, which are produced in the shikimate pathway (DUKE, 1988). Also, glyphosate is efficiently degraded in cells and aminomethylphosphonic acid (AMPA) is accumulated in seeds (DUKE et al., 2003). This substance is known to be toxic to soybean, but it affects plant development quite differently from glyphosate (HOAGLAND, 1980). Once degradation and further effects of AMPA, accumulated from glyphosate metabolization, are still not clear (REDDY; RIMANDO; DUKE, 2004), it is possible that metabolites may be degraded during storage as deterioration process evolves. 
Table 1. Variance analysis and means of germination percentage and first count, abnormal seedlings, seed mass, electrical conductivity and accelerated aging affected by desiccation of soybean plants with glyphosate and storage period.

\begin{tabular}{|c|c|c|c|c|}
\hline \multirow{2}{*}{ Evaluation } & \multirow{2}{*}{ Desiccation } & \multicolumn{2}{|c|}{ Storage period (months) } & \multirow[b]{2}{*}{ Mean } \\
\hline & & 0 & 8 & \\
\hline \multirow{7}{*}{$\begin{array}{l}\text { Germination } \\
(\%)\end{array}$} & With & $31 \mathrm{Bb}^{1}$ & $58 \mathrm{Ab}$ & $45 \mathrm{~b}$ \\
\hline & Without & $89 \mathrm{Aa}$ & $87 \mathrm{Aa}$ & $88 \mathrm{a}$ \\
\hline & Mean & $60 \mathrm{~B}$ & $73 \mathrm{~A}$ & - \\
\hline & C.V. (\%) & & 11.69 & \\
\hline & Desiccation & & $510.070 * *$ & \\
\hline & Storage period & & $41.936^{* *}$ & \\
\hline & Interaction & & $55.388 * *$ & \\
\hline \multirow{7}{*}{$\begin{array}{l}\text { First count } \\
\quad(\%)\end{array}$} & With & $11 \mathrm{Bb}$ & $32 \mathrm{Ab}$ & $22 \mathrm{~b}$ \\
\hline & Without & $86 \mathrm{Aa}$ & $80 \mathrm{Ba}$ & $83 \mathrm{a}$ \\
\hline & Mean & $49 \mathrm{~B}$ & $56 \mathrm{~A}$ & - \\
\hline & C.V. $(\%)$ & & 13.44 & \\
\hline & Desiccation & & $1231.676^{* *}$ & \\
\hline & Storage period & & $19.401 * *$ & \\
\hline & Interaction & & $61.070 * *$ & \\
\hline \multirow{7}{*}{$\begin{array}{l}\text { Abnormal seedlings } \\
(\%)\end{array}$} & With & $66 \mathrm{Bb}$ & $36 \mathrm{Ab}$ & $51 \mathrm{a}$ \\
\hline & Without & $10 \mathrm{Aa}$ & $8 \mathrm{Aa}$ & $9 \mathrm{~b}$ \\
\hline & Mean & $38 \mathrm{~B}$ & $22 \mathrm{~A}$ & - \\
\hline & C.V. $(\%)$ & & 23.85 & \\
\hline & Desiccation & & $548.412 * *$ & \\
\hline & Storage period & & $77.275^{* *}$ & \\
\hline & Interaction & & $63.150 * *$ & \\
\hline \multirow{7}{*}{$\begin{array}{c}\text { Mass of } \\
100 \text { seeds } \\
(\mathrm{g})\end{array}$} & With & $20.01 \mathrm{Aa}^{1}$ & $19.57 \mathrm{Ba}$ & $19.79 \mathrm{a}$ \\
\hline & Without & $19.86 \mathrm{Aa}$ & $18.95 \mathrm{Bb}$ & $19.40 \mathrm{~b}$ \\
\hline & Mean & $19.93 \mathrm{~A}$ & $19.26 \mathrm{~B}$ & - \\
\hline & C.V. $(\%)$ & & 3.41 & \\
\hline & Desiccation & & $10.712 * *$ & \\
\hline & Storage period & & $32.642 * *$ & \\
\hline & Interaction & & $3.852 *$ & \\
\hline \multirow{7}{*}{$\begin{array}{l}\text { Electrical conductivity } \\
\qquad\left(\mu \mathrm{S} \mathrm{cm}^{-1} \mathrm{~g}^{-1}\right)\end{array}$} & With & 78.91 & 117.27 & 98.09 \\
\hline & Without & 78.42 & 117.53 & 97.97 \\
\hline & Mean & $78.66 \mathrm{~A}$ & $117.40 \mathrm{~B}$ & - \\
\hline & C.V. (\%) & & 10.21 & \\
\hline & Desiccation & & $0.002 \mathrm{~ns}$ & \\
\hline & Storage period & & $239.463^{* *}$ & \\
\hline & Interaction & & $0.022 \mathrm{~ns}$ & \\
\hline \multirow{7}{*}{$\begin{array}{l}\text { Accelerated } \\
\text { aging } \\
(\%)\end{array}$} & With & $26 \mathrm{Bb}$ & $34 \mathrm{Ab}$ & $30 \mathrm{~b}$ \\
\hline & Without & $73 \mathrm{Aa}$ & $40 \mathrm{Ba}$ & $56 \mathrm{a}$ \\
\hline & Mean & $49 \mathrm{~A}$ & $37 \mathrm{~B}$ & - \\
\hline & C.V. (\%) & & 14.32 & \\
\hline & Desiccation & & $294.922 * *$ & \\
\hline & Storage period & & $69.946^{* *}$ & \\
\hline & Interaction & & $180.585^{* *}$ & \\
\hline
\end{tabular}

${ }^{1}$ Means followed by the same small letter in the column and capital letter in the row do not differ statistically by the Tukey test (p $\leq 0.05) . * *$ significant at a probability level of $1 \%$. C.V. - coefficient of variation

Source: Elaboration of the authors. 
As for seeds produced with no desiccation at R7, germination was not variable during storage, although difference of $6 \%$ was observed in the first count; this cited reduction was not reported in the final evaluation though (Table 1). Person's linear test justifies seed germination being increased in non-desiccated conditions and extended storage period by revealing negative correlation between percentage values of normal and abnormal seedlings, either in the first $(-0,939 * * *)$ and last $(-0,985 * * *)$ counts. Similarly, Funguetto et al. (2004) studied three methodologies to detect genetically modified soybean in conventional seed lots and observed abnormalities caused by glyphosate in germinated seeds, such as thickened points, longitudinal grooves and with yellowing of the hypocotyl, inhibition of primary root development and emission of secondary roots.

According to Table 1, seed mass and quality was decreased after 8 months of storage, regardless of the application of glyphosate as pre-harvest desiccant. By that time, it was possible to notice that mass reduction caused by deterioration processes was less accentuated in seeds harvested from desiccated plants. Electrical conductivity values at the end of storage period reflect poor quality of seeds, according to Vieira (1994), who stated that soybean lots within the limits of 60 to $70 \mu \mathrm{S} \mathrm{cm}^{-1}$ $\mathrm{g}^{-1}$ are considered of high vigor and between 70 to $80 \mu \mathrm{S} \mathrm{cm}^{-1} \mathrm{~g}^{-1}$ are considered of medium vigor. Even so, values of up to $100-110 \mu \mathrm{S} \mathrm{cm}^{-1} \mathrm{~g}^{-1}$ may be representative of satisfactory field performance if seeds are sown under adequate environmental conditions (VIEIRA; PAIVA AGUERO; PERECIN, 1999).

Harmful effects from desiccation with glyphosate were also noticed through results of the accelerated aging test (Table 1). Seeds from desiccated plants showed higher germination after a 3-day period of stress. Moisture content was uniform and varied from 26.21 to $27.31 \%$ after the aging period.

Seedling development and dry matter did not vary after 8 months of storage; nevertheless, primary root, hypocotyl and total seedling length as well as seedling dry matter were impaired by pre-harvest desiccation of soybean plants (Table 2). Results corroborated by Marcandalli, Lazarini and Malaspina (2011) revealed that reduced seedling length resulted from hypocotyl and, especially, primary root shortening $(0.880 * * *$ and $0.990 * * *$, respectively), according to Person's correlation test. According to Bervald et al. (2010), photosynthesis does not occur in early stages of seedling development due to an early stage in formation of photosynthetic apparatus. That way, seedlings do not form amino acids that are essential in the synthesis of proteins and secondary metabolites. Biosynthesis of aromatic amino acids blocked by glyphosate may decrease levels of soluble proteins in plant tissues and thus harm germination and other early processes

Tillmann and West (2004) observed that germination, hypocotyl and seedling length is negatively affected whenever non-genetically soybean seeds are emerged in glyphosate solution. Gazziero and França Neto (2008) and Daltro et al. (2010), on the other hand, applied glyphosate as desiccant in soybean plants and observed negative effects on seedling length of cultivars 'Conquista' and 'Xingu'.

Pre-harvest desiccation of plants is not to be considered routine practice. Although many studies have shown positive effects on seed quality, the application of some products is still only recommended for grain production (TECNOLOGIAS, 2011). The results clearly showed deleterious effects of glyphosate used as desiccant for early harvest of soybean seeds. Accelerating plant senescence leads to production of seeds with lower germination and decreased seedling development, although the percentage of abnormal seedlings may be reduced after 8 months of storage possibly due to degradation of toxic residues. 
Table 2. Variance analysis and means of root length, hypocotyl length, seedling length and seedling dry matter affected by desiccation of soybean plants with glyphosate and storage period.

\begin{tabular}{|c|c|c|c|c|}
\hline \multirow{2}{*}{ Evaluation } & \multirow{2}{*}{ Desiccation } & \multicolumn{2}{|c|}{ Storage period (months) } & \multirow[b]{2}{*}{ Mean } \\
\hline & & 0 & 8 & \\
\hline \multirow{7}{*}{$\begin{array}{l}\text { Root length } \\
\quad(\mathrm{cm})\end{array}$} & With & $2.21^{1}$ & 2.23 & $2.22 \mathrm{~b}$ \\
\hline & Without & 12.54 & 11.75 & $12.15 \mathrm{a}$ \\
\hline & Mean & 7.38 & 6.99 & - \\
\hline & C.V. $(\%)$ & & 21.66 & \\
\hline & Desiccation & & $650.897 * *$ & \\
\hline & Storage period & & $0.978 \mathrm{~ns}$ & \\
\hline & Interaction & & $1.106 \mathrm{~ns}$ & \\
\hline \multirow{7}{*}{$\begin{array}{l}\text { Hypocotyl length } \\
(\mathrm{cm})\end{array}$} & With & 3.19 & 2.96 & $3.07 \mathrm{~b}$ \\
\hline & Without & 5.02 & 5.49 & $5.25 \mathrm{a}$ \\
\hline & Mean & 4.10 & 4.22 & - \\
\hline & C.V. $(\%)$ & & 26.18 & \\
\hline & Desiccation & & $64.030 * *$ & \\
\hline & Storage period & & $0.190 \mathrm{~ns}$ & \\
\hline & Interaction & & $1.686 \mathrm{~ns}$ & \\
\hline \multirow{7}{*}{$\begin{array}{l}\text { Seedling length } \\
\qquad(\mathrm{cm})\end{array}$} & With & 5.40 & 5.19 & $5.29 \mathrm{~b}$ \\
\hline & Without & 17.56 & 17.24 & $17.40 \mathrm{a}$ \\
\hline & Mean & 11.48 & 11.21 & - \\
\hline & C.V. $(\%)$ & & 21.25 & \\
\hline & Desiccation & & $403.112 * *$ & \\
\hline & Storage period & & $0.195 \mathrm{~ns}$ & \\
\hline & Interaction & & $0.008 \mathrm{~ns}$ & \\
\hline \multirow{7}{*}{$\begin{array}{l}\text { Seedling dry matter } \\
\text { (mg) }\end{array}$} & With & 26.35 & 27.97 & $27.16 \mathrm{~b}$ \\
\hline & Without & 34.89 & 34.31 & $34.60 \mathrm{a}$ \\
\hline & Mean & 30.62 & 31.14 & - \\
\hline & C.V. $(\%)$ & & 13.51 & \\
\hline & Desiccation & & $50.894 * *$ & \\
\hline & Storage period & & $0.252 \mathrm{~ns}$ & \\
\hline & Interaction & & $1.111 \mathrm{~ns}$ & \\
\hline
\end{tabular}

${ }^{1}$ Means followed by the same small letter in the column and capital letter in the row do not differ statistically by the Tukey test ( $p$ $\leq 0.05)$. ${ }^{* *}$ significant at a probability level of $1 \%$; ns: not significant. C.V. - coefficient of variation.

Source: Elaboration of the authors.

\section{Acknowledgements}

To FAPESP (Fundação de Amparo à Pesquisa do Estado de São Paulo) and CNPq (Conselho Nacional de Desenvolvimento Científico e Tecnológico) for supporting scholarships to the first and second authors, respectively.

\section{References}

BERVALD, C. M. P.; MENDES, C. R.; TIMM, F. C.; MORAES, D. M.; BARROS, A. C. S. A.; PESKE, S. T. Desempenho fisiológico de sementes de soja de cultivares convencional e transgênica submetidas ao glifosato. Revista Brasileira de Sementes, Londrina, v. 32, n. 2, p. 9-18, 2010.

BRASIL. Ministério da Agricultura, Pecuária e Abastecimento. Regras para análise de sementes. Ministério da Agricultura, Pecuária e Abastecimento. Secretaria de Defesa Agropecuária. Brasília: MAPA/ ACS, 2009. 395 p. 
CARVALHO, N. M.; NAKAGAWA, J. Sementes: ciência, tecnologia e produção. 5. ed. Jaboticabal: FUNEP, 2012. $590 \mathrm{p}$.

DALTRO, E. M. F.; ALBUQUERQUE, M. C. F.; FRANÇA NETO, J. B.; GUIMARÃES, S. C.; GAZZIERO, D. L. P.; HENNING, A. A. Aplicação de dessecantes em pré-colheita: efeito na qualidade fisiológica de sementes de soja. Revista Brasileira de Sementes, Londrina, v. 3, n. 1, p. 111-122, 2010.

DICK, R. E.; QUINN, J. P. Glyphosate-degrading isolates from environmental samples: occurrence and pathways of degradation. Applied Microbiology and Biotechnology, Heidelberg, v. 43, n. 3, p. 545-550, 1995.

DUKE, S. O. Glyphosate. In: KEARNEY, P. C.; KAUFMAN, D. D. (Ed.). Herbicides: chemistry, degradation, and mode of action. New York: Dekker, 1988. p. 1-70.

DUKE, S. O.; RIMANDO, A. M.; PACE, P. F.; REDDY, N. K.; SMEDA, R. J. Isoflavone, glyphosate and aminomethylphosphonic acid levels in seeds of glyphosate-treated, glyphosate-resistant soybean. Journal of Agriculture and Food Chemistry, Davis, v. 51, n. 1, p. 340-344, 2003.

FEHR, W. R.; CAVINESS, C. E. Stages of soybean development. Ames: Iowa State University, 1977. 11 p. (Special report, 80).

FOOD AND AGRICULTURE ORGANIZATION OF THE UNITED NATIONS - FAO. World reference base for soil resources. Roma: FAO, 2006. 145 p.

FUNGUETTO, C. I.; TILLMANN, M. A. A.; VILLELA, F. A.; DODE, L. B. Detecção de sementes de soja geneticamente modificada tolerante ao herbicida glifosato. Revista Brasileira de Sementes, Londrina, v. 26, n. 1, p. 130-138, 2004.

GAZZIERO, D. L. P.; FRANÇA NETO, J. B. Dessecação em pré-colheita e seus efeitos sobre a qualidade da semente de soja. Londrina: Embrapa Soja, 2008. Disponível em: <http://www.cnpso.embrapa.br/ download/palestras/glyphosate-dionisio-franca.pdf $>$. Acesso em: 21 jul. 2013.

HOAGLAND, R. E. Effects of glyphosate on metabolism of phenolic compounds: VI-effects of glyphosine and glyphosate metabolites on phenylalanine ammonialyase activity, growth, and protein, chlorophyll, and anthocyanin levels in soybean (Glycine max) seedlings. Weed Science, Lawrence, v. 28, n. 4, p. 393-400, 1980.
HOAGLAND, R. E.; DUKE, S. O. Relationships between phenylalanine ammonia-lyase activity and physiological responses of soybean (Glycine max) seedlings to herbicides. Weed Science, Lawrence, v. 31, n. 6, p. 845-852, 1983.

HOLLIDAY, M. J.; KEEN, N. T. The role of phytoalexins in the resistance of soybean leaves to bacteria: effect of glyphosate on glyceollin accumulation. Phytopathology, St. Paul, v. 72, n. 11, p. 1470-1474, 1982.

LACERDA, A. L. S.; LAZARINI, E.; SÁ, M. E.; VALÉRIO FILHO, W. V. Armazenamento de sementes de soja dessecadas e avaliação da qualidade fisiológica, bioquímica e sanitária. Revista Brasileira de Sementes, Londrina, v. 25, n. 2, p. 97-105, 2003.

MARCANDALLI, L. H.; LAZARINI, E.; MALASPINA, I. C. Épocas de aplicação de dessecantes na cultura da soja: qualidade fisiológica de sementes. Revista Brasileira de Sementes, Londrina, v. 33, n. 2, p. 241-250, 2011.

MARCOS FILHO, J. Teste de envelhecimento acelerado. In: KRZYZANOWSKI, F. C.; VIEIRA, R. D.; FRANÇA NETO, J. B. (Ed.). Vigor de sementes: conceitos e testes. Londrina: ABRATES, 1999. p. 3.1-3.24.

MENDEZ DEL VILLAR, P.; FERREIRA, C. M.; RIBEIRO, J. G. B. L.; MEDEIROS, J. X.; LUBELLO, P.; FOK, M. Private governance in royalty collection effectiveness and limitations in tracing GM soybean in Brazil. In: INTERNATIONAL CONFERENCE ON COEXISTENCE BETWEEN GENETICALLY MODIFIED (GM) AND NON-GM BASED AGRICULTURAL SUPPLY CHAINS, 3., 2007, Sevilla. Abstracts... Sevilla: European Comission, 2007. p. 163164.

NAKAGAWA, J. Testes de vigor baseados no desempenho das plântulas. In: KRZYZANOWSKI, F. C.; VIEIRA, R. D.; FRANÇA NETO, J. B. (Ed.). Vigor de sementes: conceitos e testes. Londrina: ABRATES, 1999. p. 2.9-2.13.

PENCKOWSKI, L. H.; PODOLAN, M. J.; LÓPEZOVEJERO, R. F. Efeito de herbicidas aplicados na précolheita na qualidade fisiológica das sementes de feijão. Revista Brasileira de Herbicidas, Maringá, v. 4, n. 2, p. 102-113, 2005.

REDDY, K. N.; RIMANDO, A. M.; DUKE, S. O. Aminomethylphosphonic acid, a metabolite of glyphosate, causes injury in glyphosate-treated, glyphosate-resistant soybean. Journal of Agriculture and Food Chemistry, Davis, v. 52, n. 16, p. 5139-5143, 2004. 
TECNOLOGIAS de produção de soja - Região Central do Brasil 2012 e 2013. Londrina: Embrapa Soja, 2011. 264 p. (Sistemas de Produção, 15).

TILLMANN, M. A. A.; WEST, S. Identification of genetically modified soybean seeds resistant to glyphosate. Scientia Agricola, Piracicaba, v. 26, n. 3, p. 336-341, 2004.

VARGAS, L.; MORAES, R. M. A.; BERTO, C. M. Herança da resistência de azevém (Lolium multiflorum) ao glyphosate. Planta Daninha, Viçosa, v. 25, n. 3, p. 567-571, 2007.
VIEIRA, R. D. Teste de condutividade elétrica. In: VIEIRA, R. D.; CARVALHO, N. M. (Ed.). Testes de vigor em sementes. Jaboticabal: FUNEP, 1994. p. 103132.

VIEIRA, R. D.; KRZYZANOWSKI, F. C. Teste de condutividade elétrica. In: KRZYZANOWSKI, F. C.; VIEIRA, R. D.; FRANÇA NETO, J. B. (Ed.). Vigor de sementes: conceitos e testes. Londrina: ABRATES, 1999. p. 4.1-4.26.

VIEIRA, R. D.; PAIVA AGUERO, J. A.; PERECIN, D. Electrical conductivity and field performance of soybean seeds. Seed Technology, Moline, v. 21, n. 1, p. 15-24, 1999. 
